\title{
Composition, community structure, and vertical distribution of epiphytic ferns on Cyathea junghuhniana in Gede-Pangrango National Park, Indonesia
}

\author{
USWATUN HASANAH ${ }^{1}$, HADISUNARSO ${ }^{1}$, TITIEN NGATINEM PRAPTOSUWIRYO ${ }^{2, \bullet}$ \\ ${ }^{1}$ Department of Biology, Faculty of Mathematics and Sciences, Institut Pertanian Bogor. Institut Pertanian Bogor. Jl. Meranti, IPB University Campus \\ Dramaga, Bogor 16680, West Java, Indonesia \\ ${ }^{2}$ Research Center for Plant Conservation and Botanic Gardens (Bogor Botanic Gardens), National Agency for Research and Innovation. J1. Ir. H. Juanda \\ No. 13, Bogor 16022, West Java, Indonesia. Tel./fax: +62-251-8322187, `email: tienpferns@gmail.com
}

Manuscript received: 3 June 2021. Revision accepted: 24 October 2021.

\begin{abstract}
Hasanah U, Hadisunarso, Praptosuwiryo TN. 2021. Composition, community structure, and vertical distribution of epiphytic ferns on Cyathea junghuhniana in Gede-Pangrango National Park, Indonesia. Biodiversitas 22: 4968-4976. Epiphytic ferns are a significant component of tropical forests worldwide and contribute significantly to the high species diversity found in tropical regions. Tree ferns are important phorophytes for the establishment and occurrence of epiphytic fern species in tropical forests. The first detailed description of the diversity and abundance of epiphytic ferns on the tree fern Cyathea junghuhniana (Kunze) Copel. in a natural forest of Indonesia is provided. This study aimed to determine the species composition, richness, abundance, community structure, and vertical distribution of epiphytic ferns growing on the tree fern $C$. junghuhniana in the mountain forest of Gede-Pangrango National Park, West Java, Indonesia. The 35 tree fern caudices of at least $3 \mathrm{~m}$ height were selected by purposive random sampling. Each tree fern was divided into intervals of 1 meter from ground level to a height of three meters, thus obtaining 105 one-meter samples of the epiphytic fern community on tree fern caudices stratified according to height. The Importance Value Index (IVI) was estimated for each species of epiphyte based on the frequency of occurrence on caudices. The 35 tree fern caudices hosted 760 fern epiphytes belonging to 12 species of 9 genera and 6 families. The highest species richness occurred in Polypodiaceae. The species with the highest Importance Value Index $(\mathrm{IVI}=1.24 \%$ ) was Nephrolepis davallioides $(\mathrm{Sw}$.) Kunze, with increasing frequency from bottom to top of the caudex.
\end{abstract}

Keywords: Cyathea junghuhniana, species richness, tree fern phorophyte, wet tropical forest

\section{INTRODUCTION}

Epiphytes are a significant component of tropical forests worldwide and contribute significantly to high species diversity found in tropical regions (de la RosaManzano et al. 2019; Wang et al. 2016). Epiphytes contribute profoundly to the forest diversity and ecosystem processes as the plants have versatile adaptations to a life above ground level and have a vast abundance (Batke 2012). More than 27600 species of vascular epiphytes represent 913 genera in 73 families that occur mainly in tropics (Zotz 2013). Epiphytes are important habitat and food source for birds and mammals (Gotsch 2016). In the tropical forest canopies, epiphytic ferns often represent some of the most abundant taxa (Gonzalez et al. 2017) and can dominate epiphyte biomass (Watkins Jr. and Cardelus 2012). Epiphytes are very important for organisms living on canopy because they serve a cool and moist microhabitat in the relatively hot and dry canopy (Scheffers et al. 2014). Díaz et al. (2012) reported that trees with epiphytes have greater invertebrate species richness compared with trees without epiphytes.

Epiphytes are also important for biogeochemical processes. Some epiphytes create favorable microsites for free-living nitrogen-fixing bacteria (Brighigna et al. 1992). Due to their high growth efficiency, including leaf production and root growth, epiphytes make more enormous contributions to primary productivity, litterfall, and nutrient cycling (Hegarty 1991). Epiphytes provide animals with considerable resources, including food, water, nesting materials and habitat (Gotsch et al. 2016). Epiphytic plants are also an important component for models and studies of canopy environments because they have strong effects on host plant ecophysiology and forest ecosystem processes (Stanton et al. 2014). Although we have understood that epiphytic plants are important components of the forest ecosystem, however little is known about their ecology due to logistical constraints and the lack of a conceptual framework to guide epiphyte community studies (Bartels and Chen 2012).

Both in tropical and temperate, species of tree-fern provide favorable habitat for many epiphytic bryophyte and fern species (Medeiros et al. 1993; Schneider and Schmitt 2011). Tree-ferns widen their stems effectively by investing it with a layer of dense, hard, black, intertwined roots and resulting 'trunk' that is technically referred to as a caudex (Roberts et al. 2005). The root mantles provide favorable microhabitats for the establishment of fern prothalli and a substrate for the attachment of fern sporophytes (Moran et al. 2003). Tree ferns have numerous key ecological roles; they provide food, nesting sites, and movement pathways for animals and being host sites for a wide diversity of epiphytic plants (Blair et al. 2017). Unfortunately, most species of tree ferns, Cyathea, are 
collected and harvested illegally so that their population tends to be decreasing in the wild. Cyathea spp. have become a high priority focus for many scientists (Lehnert et al. 2019) because these ancient and conspicuous plants are listed as endangered in the index of CITES (CITES 2019) to restrict and control their trade. In Indonesia and other countries, such as in Colombia (Eleuterio and PerezSalicrup 2006), the trunks of Cyatheaceae with their fibrous root mantle are locally used for substrates for epiphytic plants, making special flowerpots, and other crafts. Reducing the population of Cyathea would threaten the species richness and abundance of the epiphytic ferns as these plants are most severely affected by habitat destruction (Aguirre et al. 2010). Tree ferns can be an indicator of undisturbed areas as their growth is directly related to forest successional stage; they can also be used as an alert that the area has suffered degradation (Castelloa et al. 2017).

The ecology of fern species is generally poorly understood, even though such knowledge is very important for biodiversity-protection measures in forest management. For the last 250 years, fern research was primarily given attention to systematics, taxonomy, and morphology, floristic, ethnobotany, and more recently on molecular phylogenetics studies and there were only about $4 \%$ of annual fern publications indexed as ecological studies (Mehltreter and Hooper 2013). In addition, most recent studies on the ecology, floristic, and diversity of epiphytic ferns were reported outside of the Malesian region (Bianchi and Kersten 2014; Chambers et al. 2017; Díaz et al. 2012; Eskova et al. 2020; Gabriel y Galaân et al. 2018, Gonzalez et al. 2017; Huang et al. 2019; Klinghardt and Zotz 2021; Lu et al. 2015; Machado et al. 2016; Moulatlet et al. 2019; Mountier et al. 2018; Nagalingum et al. 2015; Nettesheim et al. 2014; Nitta et al. 2020; Oldekop et al. 2012; Pouteau et al. 2016; Quaresma et al. 2017; Ramírez-Barahona et al. 2011; Riefner Jr. and Smith 2019; Sanger and Kirkpatrick 2015; Schmitt and Windisch 2010; Sugita et al. 2013; Testo and Watkins 2013; Wagner et al. 2015). Ecological studies dealing with the composition, community structure, and vertical distribution of epiphytic tree ferns outside of the Malesian region have been reported (Bittner and TrejosZelaya 1997; Roberts et al. 2005; Fraga et al. 2008; Scheider and Schmitt 2011). A study on the diversity and composition of the epiphytic vascular plant, including ferns, on tree ferns (Cyathea spp.) growing in Cibodas Botanic Garden, West Java, Indonesia, was reported by Nasution and Junaedi (2017). However, studies dealing with the epiphytic ferns growing on the tree ferns in natural habitats, especially from tropical wet mountains of Java, have not been reported in the literature.

We present quantitative information on species richness of ferns epiphytes growing on tree-fern trunks in the wet tropical forest of West Java, Indonesia. The objective of this study was to determine the species composition, richness, abundance, community structure, and vertical distribution of epiphytic ferns growing on the tree fern Cyathea junghuhniana (Kunze) Copel. in the mountain forest of Gede-Pangrango National Park. We aimed to answer three questions: How are the diversity and floristic composition of epiphytic ferns growing on the trunk of $C$. junghuhniana? (i); How many samples of individual tree fern can be used to estimate the species richness of the epiphytic fern growing on tree fern in wet tropical high mountains of Java? (ii); How is the vertical distribution and covered percentage of epiphytic ferns on the tree fern? (iii).

\section{MATERIALS AND METHODS}

\section{Study site}

The present study was carried out in Gede-Pangrango National Park (GPNP), Indonesia. The park is a protected area of the tropical mountain rain forest ecosystem situated at $06^{\circ} 50^{\prime}-07^{\circ} 02^{\prime} \mathrm{E}$ and $06^{\circ} 41^{\prime}-06^{\circ} 51^{\prime} \mathrm{S}$. This region is located among 3 three districts of West Java Province, viz. Bogor District, Cianjur District, and Sukabumi District (Figure 1). GPNP is a representative of the mountain rain forest ecosystem in Java (Ditjen PHKA 2008).

Based on the altitudinal zone proposed by van Steenis (1972) the vegetation zone of Mt. Gede-Pangrango is divided into five zones, namely: Lowland Zone (5-500 m), Collin Zone (500-1000 m), Submontane Zone (1000-1500 $\mathrm{m})$, Montane Zone (1500-2400 m), and Subalpine Zone (2400-3019 m). This national park is divided into seven zonas based on the characteristics, sensitivity of areas, and usage, namely: Core zone, forest zone, utilization zone, the traditional zone, rehabilitation zone, Javanese Owa conservation zone, and special zone ( et al. 2015). According to the climatic classification of Schmidt Ferguson, GPNP region is included in Type A $(\mathrm{Q}$ value $=$ $5-9 \%$ ). The average annual rainfall is 3,000-4,200 $\mathrm{mm}$. The temperature average is $5^{\circ} \mathrm{C}-10^{\circ} \mathrm{C}$ in the summit of $\mathrm{Mt}$. Gede-Pangrango and $10^{\circ} \mathrm{C}-18^{\circ} \mathrm{C}$ in the lower areas with the humidity around $80-90 \%$ (Mulyana et al. 2015).

GPNP is an evergreen forest that covers an area of about 22,851.03 hectares (Gunawan et al. 2011). This region is home to a huge diversity of plants. More than 1,000 species included in 120 families of flowering plants have been recorded. Most flowering plants growing between 1000-2000 $\mathrm{m}$ asl are belonging to the families Annonaceae, Apocynaceae, Araceae, Ascleipiadaceae, Connaraceae, Cucurbitaceae, Euphorbiaceae, Leguminaceae, Menispermaceae, Myristicaceae, Palmaceae, Rhamnaceae, Sapindaceae, Thymelaeaceae, Vitaceae, Zingiberaceae, and Cyatheaceae (van Steenis 1972). Tree ferns species of the genus Cyathea are also an important component of the mountain forest of Gede-Pangrango (Holttum 1965).

\section{Study species}

Cyathea junghuhniana (Kunze) Copel. is a tree fern belonging to the family Cyatheaceae. Its synonym is Alsophila junghuhniana Kunze. This species is recognized by diagnostic characteristics as follows: Pneumathodes on stipe 5-14 mm long, in a double or triple row; Bullate scales present only on costules; Lower surface of pinnarachis not closely hairy throughout; Pinnules often $10 \mathrm{~cm}$ long, acuminate; Indusia not forming a distinct cup nor covering sorus, attached only on costular side of the receptacle and often inconspicuous. This species is only 
found in the Malesian region and distributed in South and Central Sumatra, and Java (Holttum 1965).

\section{Sampling and plant identification.}

For the epiphytic community study, 35 caudices of $C$. junghuhniana having at least $3 \mathrm{~m}$ high were chosen using purposive random sampling. Sampling was carried out at along the hiking trail from Cibodas to the Cibeureum waterfall (106 $59^{\prime} 578^{\prime \prime}$ E, 06 $44^{\prime} 13^{\prime \prime} \mathrm{S}$ to $106^{\circ} 57^{\prime} 28^{\prime \prime}$, $06^{\circ} 50^{\prime} 23^{\prime \prime} \mathrm{S}$ ), from 1380 to $1625 \mathrm{~m}$ asl., in submontanemountain zones, of the Mandalawangi Resort (Figure 1). The caudices were divided into one-meter intervals from the ground up to $3 \mathrm{~m}$, totaling 105 intervals. The fibrous layer known as the "root mantle" of this species is thicker at a hight of 1 meter from ground level to three meters (pers. obs.). The root mantle of tree ferns is widest at the base of the trunk and narrows upward and provides an excellent substrate for epiphytes, including ferns epiphytes (Moran et al. 2003). Species determinations of epiphytic ferns growing on the tree fern were performed by consulting Piggott and Piggot (1988), Hovenkamp et al. (1998). The classification system follows PPG I (2016). Definition for epiphytic classification follows Zotz (2016).

\section{Species richness estimation}

We used the species accumulation curve to estimate species richness of epiphytic ferns growing on the tree fern C. junghuhniana. The species accumulation curve plots the expected number of detected species as a function of sampling effort. One approach to sampling a species assemblage is to record whether or not each species is detected in a set of randomly selected sampling units. The term "quadrats" will refer to such sampling units, including areas of various shapes and sizes, traps, lures, mist nets, etc. (Mao et al. 2005). Species accumulation curves allow researchers to assess and compare diversity across populations (Deng et al. 2015). The species richness of epiphytic ferns growing on the trunk of $C$. junghuhniana was estimated by figuring out the species accumulation curve by using Microsoft Excell 97-2003. Species richness was measured as the total number of species of epiphytic ferns growing on the observed trunk of $C$. junghuhniana.

\section{Community structure}

The community structure of epiphytic ferns growing on the tree fern was figured by the value of the Absolute Frequency (AF), Relative Frequency (RF), Absolute Density (AD), and Relative Density (RD) (Schneider and Schmitt 2011) and then the importance value index (IVI) was calculated. The absolute frequency of epiphytic fern species was calculated by counting the individual tree fern where the species were found growing. The result was then divided by the total individual of tree fern observed. Relative frequency: the result of dividing the absolute frequency of a species by the total number of the data. The absolute density of a species is calculated by dividing the individual number of species by the surface area of the trunk. The surface area of the trunk can be obtained from the circumference of the tree trunk multiplied by the height of the tree trunk, which is equal to 3 meters. Relative density can be calculated by the density of species A divided by the total density of the species then multiplied by $100 \%$.

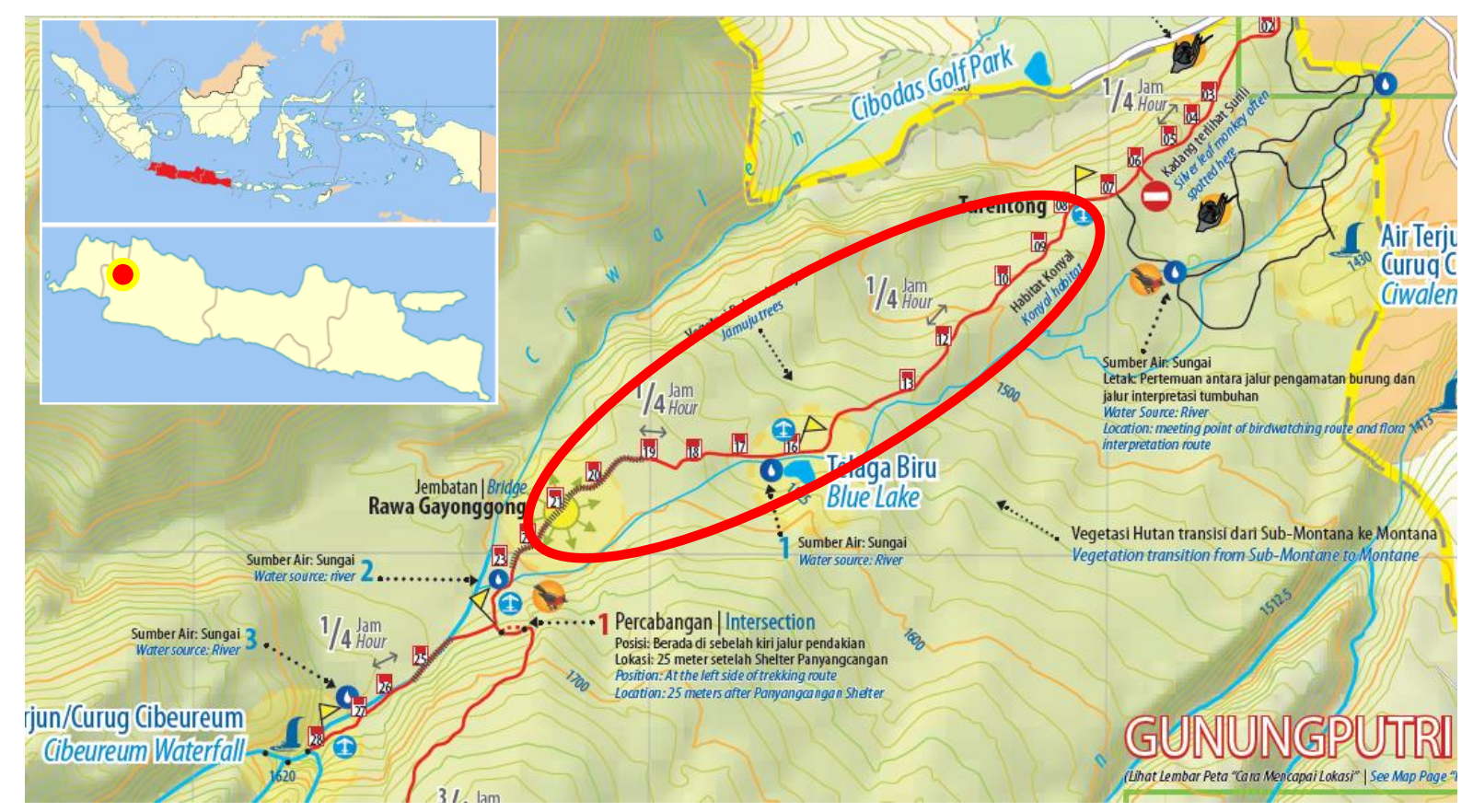

Figure 1. Map of the hiking trail from Cibodas to the Cibeureum waterfall, Gede-Pangrango National Park, showing CibodasCibeureum Waterfalls-Kandang Badak Trails, track area of the observations of epiphytic ferns growing on the trunk of Cyathea junghuhniana. The study area is marked with red line circle. Source: Trekking Map of Gede-Pangrango National Park 
The importance value index (IVI) for each epiphytic fern species was calculated by using Mueller-Dombois and Ellenberg (1974). IV $=$ relative dominance + relative frequency + relative density. Using the IVI, we calculated the Shannon-Wiener diversity index $\left(\mathrm{H}^{\prime}\right)$ as follows: $\mathrm{H}^{\prime}=$ $-\Sigma$ pi ln pi, where pi $=\mathrm{ni} / \mathrm{N}$, ni is the IVI of species $\mathrm{i}$, and $\mathrm{N}$ is total IVI (Michael 1984). The evenness index (e) was calculated by using Pilou's formula: $\mathrm{e}=\mathrm{H}^{\prime} / \mathrm{ln} \mathrm{S}$, where the Shannon-Wiener diversity index of each stand and $\mathrm{S}$ is the total number of species in the stand (Odum 1993).

\section{Data analysis}

Data were analyzed descriptively and statistically. The species abundance differences of epiphytic ferns among the tree intervals were analyzed by using One-way ANOVA using SPSS (Statistical Product and Service Solutions) 16.0 program.

\section{RESULTS AND DISCUSSION}

\section{Diversity and floristic composition of epiphytic ferns growing on the trunk of Cyathea junghuhniana Floristic composition}

The diversity and floristic composition of epiphytic ferns growing on the trunk of $C$. junghuhniana are presented in Table 1. The 35 tree fern caudices hosted a total of 760 fern epiphytes belonging to 12 species of 9 genera and 6 families. The families with high species numbers were recorded in Polypodiaceae (5 species) and Aspleniaceae ( 3 species). This finding is in line with the previous studies in Costa Rica (de la Sota 1971), Colombia (de la Sota 1972), in Southern Brazil (Fraga et al. 2008; Schmitt 2006). The family Polypodiaceae were also the most prominent epiphytic ferns growing on the host trees of the Pan Yi river basin in Thailand (Hayasaka 2012), in the region of Los Tuxtlas, Veracruz, Mexico (Acebey et al. 2017), and at Thekwini Municipal Area, South Africa (Bhatt et al. 2015). Polypodiaceae is among the richest families in species of the epiphytic ferns surveys reported by Nasution and Junaidi (2017) in Cibodas Botanic Gardens (Indonesia), Praptosuwiryo et al. (2019) in Bogor Botanic Gardens, and Jiménez-López et al. (2020) in Mexico. Recently studies on the epiphytic ferns growing on the tree fern Alsophila setosa Kaulf. in the deciduous forest in Morro Reuter, Brazil revealed that $71.43 \%$ of the species recorded were also belonging to the family Aspleniaceae and Polypodiaceae. Aspleniaceae and Polypodiaceae were recorded as dominant families along elevation gradients in Kolli Hills of the Eastern Ghats, India (Sureshkumar 2020). The two families are fern groups with a high species abundance in the world (Holttum 1966; Kramer and Viane 1990). Many species of Aspleniaceae, especially of the genus Asplenium, grow as epiphytes and are distributed all over the world; the majority are in the (sub)humid tropics and south temperate regions (Kramer and Viane 1990). Polypodiaceae is a rich family that consists of nearly 1,000 species distributed in almost all tropical and sub-tropical regions (Holttum 1966).
Table 1. Family and species of epiphytic ferns growing on the tree fern Cyathea junghuhniana (Kunze) Copel. with their ecological categories

\begin{tabular}{|c|c|}
\hline Species & $\begin{array}{l}\text { Ecological } \\
\text { category }\end{array}$ \\
\hline \multicolumn{2}{|l|}{ Aspleniaceae } \\
\hline Asplenium nidus L. & HAB \\
\hline Asplenium sublaserpitifolium Ching. & HAB \\
\hline $\begin{array}{l}\text { Asplenium tenerum G. Forst, var. pallidum } \\
\text { (Blume) Veldk. \& Wardani. }\end{array}$ & $\mathrm{HAB}$ \\
\hline Asplenium tenerum var. tenerum G. Forst. & HAB \\
\hline \multicolumn{2}{|l|}{ Davalliaceae } \\
\hline Davallia solida (G. Forst.) Sw. & $\mathrm{HAB}$ \\
\hline \multicolumn{2}{|l|}{ Dryopteridaceae } \\
\hline Davallia solida (G. Forst.) Sw. & $\mathrm{HAB}$ \\
\hline \multicolumn{2}{|l|}{ Dryopteridaceae } \\
\hline Dryopteris hirtipes (B1.) Kuntze. & $\mathrm{ACI}$ \\
\hline \multicolumn{2}{|l|}{ Nephrolepidaceae } \\
\hline Nephrolepis davallioides (Sw.) Kunze. & HAB \\
\hline \multicolumn{2}{|l|}{ Polypodiaceae } \\
\hline Belvisia spicata (L.F.) Copel. & $\mathrm{HAB}$ \\
\hline Goniophlebium subauriculatum (B1.) Presl. & $\mathrm{HAB}$ \\
\hline Goniophlebium persicifolium (Desv.) Bedd. & $\mathrm{HAB}$ \\
\hline Microsorum sp. & HAB \\
\hline Prosaptia obliquata (B1.) Mett. & $\mathrm{HAB}$ \\
\hline \multicolumn{2}{|l|}{ Vittariaceae } \\
\hline Vittaria elongata $\mathrm{Sw}$. & HAB \\
\hline
\end{tabular}

Most epiphytic ferns growing on the trunk of tree ferns C. junghuhniana belong to the holoepiphytic category, viz. in equal to $92 \%$. The results were in line with the studies reported by Schmitt et al. (2005) and Fraga et al. (2008) who worked on the epiphytic ferns growing on the tree fern Dicksonia sellowiana Hook. (Dicksoniaceae) in South Brazil. The holoepiphytic life-forms was also reported as predominant for tropical forests canopies (i.e. Zotz 2013), including in floodplain ecosystems (Várzea and Igapó) in the Central Amazon (Quaresma et al. 2017), Amazonian terra firme (Boelter et al. 2015), and coastal forests (Quaresma and Jardim 2014). In general, holoepiphytic plants are usually found on certain areas of tree species with relatively high numbers (Burns and Zotz 2010).

Dryopteris hirtipes (BI.) Kuntze that usually grows terrestrially (Mandal et al. 2020; Price 1977) was only found on the first level of the caudice of $C$. junghuhniana. $D$. hirtipes are mostly growing on the mountain forest at 1350-2650 $\mathrm{m}$ a.s.l. (Price 1977). Terrestrial ferns were often found to grow on the basal trees. Therefore, we classified $D$. hirtipes as accidental holoepiphytes.

\section{Species richness}

Species richness is a prime measure of community and regional diversity and underlies many ecological models that are analyzed by a number of species recorded in the samples (Tessler et al. 2016). Ecologists have used species accumulation curves to perform quantitative comparisons among species assemblages (Gotelli and Colwell 2001). it is also used to estimate the expected number of new species to be detected, given a level of additional sampling effort (Shen et al. 2003). Data analyzed from the observations of epiphytic ferns growing on 35 caudices of $C$. junghuhniana 
resulted in the graphic with the equation $\mathrm{Y}=2.262 \mathrm{Ln}(\mathrm{X})+$ 2.902 with $\mathrm{R}^{2}=0.911$ (Figure 2). The graphic illustrates that the number of species increased significantly when the number of host tree samples was between 5-27 individuals, $v i z$. from seven species to eleven species. The horizontal line occurred when sample numbers were 30-35 of individual tree fern. Thus, it is revealed that 35 individual trees are enough to figure out the species richness of epiphytic ferns growing on tree fern $C$. junghuhniana on the Cibeureum Waterfall Track of GPNP, at 1380-1625 m a.s.l. Increasing in sample number between 30-35 only resulted in the addition of one species. Species of epiphytic growing on C. junghuhniana in GPNP are provided in Table 1 .

The total number of epiphytic ferns encountered growing on the tree trunk of $C$. junghuhniana in the study area is relatively high for this park. A total of 12 ferns species representing 9 genera and 6 families growing on the 35 individual trunks of this species were recorded. Schneider and Schmitt (2011) recorded 14 species of epiphytic ferns representing 10 genera and 6 families growing on the trunks of 60 individuals of tree fern Alsophila setosa Kaulf in Brazil. It indicated that species richness of epiphytic ferns growing on the tree trunk of the tropical wet mountain forest of Java is relatively higher than in Brazil. Humidity is one of the important factors determining the species richness or epiphytic ferns growing on tree ferns. Fraga et al. (2008) reported 20 species of epiphytic ferns on caudices of Dicksonia sellowiana Hook. in mixed humid forest. It is revealed that trunk characteristics govern the species richness of epiphytic ferns growing on tree ferns. It should be noted that $D$. sellowiana has a thick cover of adventitious roots on its caudex, forming a substratum with more porosity and water retention (Fraga et al. 2008) compared with Alsophila setosa and C. junghuhniana. Zotz and Schultz (2008) stated that different types of host trees would provide different substrate, because it corresponds to the texture, porosity to water, $\mathrm{pH}$, nutrient content, litter characteristic, and moss covering. Zotz and Schultz (2008) stated that physical and chemical factors have an important role in influencing the distribution and abundance of vascular epiphytic plants.

\section{Community structure of epiphytic ferns growing on Cyathea junghuhniana}

Importance Value Index (IVI) is used to describe the level of occupancy of a species in the community, the greater IVI of species the greater level of occupancy in the community and vice versa (see Ismail et al. 2017; Quaresma et al. 2017; Schwartz and de Gasper 2020). Table 2 presents an IVI of each species growing on the tree fern $C$. junghuhniana. The highest IVI occurred in Nephrolepis davalliodes (Sw.) Kunze with a value of 1.24\%. Davallia solida (G. Forst.) Sw., with IVI $0.12 \%$ was in the second position. Species that have an intermediate of IVI were Vittaria elongata Sw., Sy. Fil. $(0.08 \%)$ and Asplenium nidus L. $(0.11 \%)$. Species with the lowest of IVI $(0.03 \%$.) occurred in Dryopteris hirtipes and Microsorum sp. Nasution and Junaedi (2017) recorded five dominant species of ferns growing on trunk of $C$. junghuhniana in Cibodas Botanic Gardens, West Java, viz. Nephrolepis biserrata (Sw.) Schott, Aslenium nidus L., Schellolepis subauriculata (Blume) J.Sm. Davallia trichomanoides Blume, and Vittaria elongata Sw. The name has been superseded by Goniophlebium subauriculatum (Bl.) Presl. (Rödl-Linder 1990).

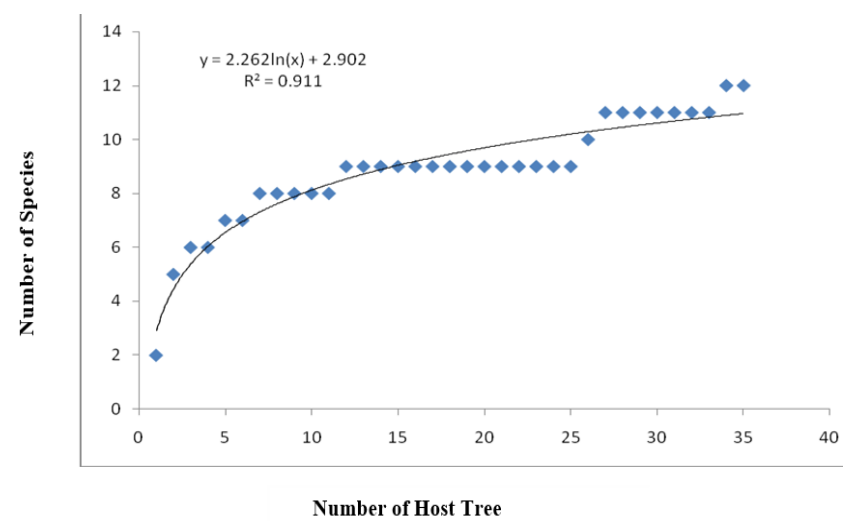

Figure 2. Species richness estimation of epiphytic ferns growing on the tree fern Cyathea junghuhniana

Table 2. Community structure of epiphytic ferns sampled on trunk of Cyathea junghuhniana in wet mountain forest of Gede-Pangrango National Park, West Java, Indonesia

\begin{tabular}{|c|c|c|c|c|c|c|}
\hline Species & $\Sigma$ individual & $\mathbf{A F}$ & RF (\%) & AD & RD $(\%)$ & IVI $(\%)$ \\
\hline Asplenium nidus $\mathrm{L}$. & 36 & i. 314 & 0.105 & 0.016 & 0.006 & 0.111 \\
\hline Asplenium sublaserpitifolium Ching. & 22 & 0.171 & 0.057 & 0.017 & 0.006 & 0.064 \\
\hline Asplenium tenerum var. pallidum (Blume) Veldk. \& Wardani & 9 & 0.086 & 0.029 & 0.016 & 0.006 & 0.035 \\
\hline Asplenium tenerum var. tenerum $\mathrm{G}$. Forst. & 8 & 0.057 & 0.019 & 0.014 & 0.005 & 0.025 \\
\hline Davallia solida (G. Forst.) Sw. & 65 & 0.314 & 0.105 & 0.029 & 0.011 & 0.116 \\
\hline Dryopteris hirtipes (B1.) Kuntze. & 8 & 0.086 & 0.029 & 0.007 & 0.003 & 0.031 \\
\hline Nephrolepis davallioides (Sw.) Kunze. & 478 & 0.971 & 0.324 & 2.358 & 0.914 & 1.238 \\
\hline Belvisia spicata (L.F.) Copel. & 16 & 0.114 & 0.038 & 0.031 & 0.012 & 0.050 \\
\hline Goniophlebium subauriculatum (B1.) Presl. & 34 & 0.371 & 0.124 & 0.012 & 0.005 & 0.129 \\
\hline Goniophlebium persicifolium (Desv.) Bedd. & 27 & 0.200 & 0.067 & 0.020 & 0.008 & 0.074 \\
\hline Microsorum sp. & 4 & 0.086 & 0.029 & 0.006 & 0.002 & 0.031 \\
\hline Prosaptia obliquata (B1.) Mett. & 5 & 0.029 & 0.010 & 0.022 & 0.009 & 0.018 \\
\hline Vittaria elongata $\mathrm{Sw}$. & 52 & 0.200 & 0.067 & 0.032 & 0.012 & 0.079 \\
\hline
\end{tabular}

Note: AF: Absolute Frequency; RF: Relative Frequency; AD: Absolute density; RD: Relative Density; IVI: Important Value Index 


\section{Vertical distribution of epiphytic fern species on the tree trunk of Cyathea junghuhniana}

The vertical distribution of epiphytic ferns growing on the trunk of $C$. junghuhniana is provided in Figure 3. Individual epiphytic ferns growing on the third interval were much more than those growing on the other intervals. The statistics test results indicate that the number of species and coverage percentage significantly affect the species abundance at each trunk interval. The most abundant epiphytic fern species at each interval of the tree trunk of C. junghuhniana is species of the family Nephrolepidaceae, namely Nephrolepis davallioides (Figure 3, Table 3). The species grows both as terrestrial and epiphytic plants. This species is usually found in forest, terrestrial, often on roadside or stream banks. However, this species is more often epiphytic and grows on trunks (Hovenkamp and Miyamoto 2005).

Light and water availability largely influences the vertical distribution of epiphytic ferns (Steege and Cornelissen 1989). Light and water coming in through the sidelines of the forest canopy are affected by the shape or the branching pattern of a tree canopy (Zotz 2007).
Availability of suitable substrate also affects the formation and growth of epiphytes that influence their vertical distribution (Nieder et al. 2000).

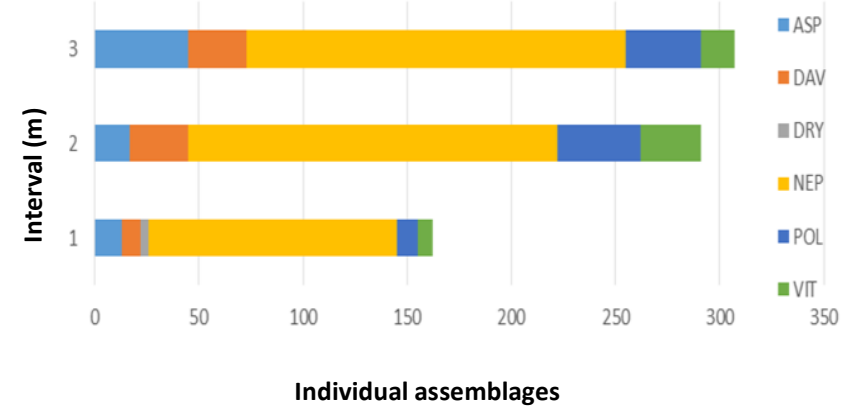

Figure 3. Species assemblage of epiphytic ferns and its partition among families by height intervals on Cyathea junghuhniana. ASP: Aspleniaceae; DAV: Davalliaceae; DRY: Dryopteridaceae; NEP: Nephrolepidaceae; POL: Polypodiaceae; VIT: Vittariaceae

Table 3. Occurrence distribution (\%) of epiphytic ferns species sampled on height intervals of Cyathea junghuhniana in GedePangrango National Park, West Java, Indonesia

\begin{tabular}{lcccc}
\hline Spesies & $\mathbf{m 1}(\boldsymbol{\%})$ & $\mathbf{m 2}(\boldsymbol{\%})$ & $\mathbf{m 3}(\boldsymbol{\%})$ & Total $(\boldsymbol{\%})$ \\
\hline Asplenium nidus L. & 0.00 & 2.20 & 18.70 & 20.90 \\
Asplenium sublaserpitifolium Ching. & 2.33 & 1.17 & 1.33 & 4.83 \\
Asplenium tenerum var. pallidum Blume) Veldk. \& Wardani. & 0.00 & 0.00 & 12.50 & 12.50 \\
Asplenium tenerum var. tenerum G. Forst. & 2.00 & 0.33 & 3.33 & 5.67 \\
Davallia solida (G. Forst.) Sw. & 1.00 & 2.64 & 2.60 & 6.24 \\
Dryopteris hirtipes (B1.) Kuntze. & 3.00 & 0.00 & 0.00 & 3.00 \\
Nephrolepis davallioides (Sw.) Kunze. & 6.79 & 12.56 & 24.15 & 43.49 \\
Belvisia spicata (L.F.) Copel. & 0.00 & 8.88 & 8.00 & 16.88 \\
Goniophlebium subauriculatum (B1.) Presl. & 0.67 & 1.00 & 0.33 & 2.00 \\
Goniophlebium persicifolium (Desv.) Bedd. & 0.46 & 1.75 & 1.15 & 3.37 \\
Microsorum sp. & 1.57 & 2.00 & 3.57 & 7.14 \\
Prosaptia obliquata (Bl.) Mett. & 0.50 & 2.00 & 0.00 & 2.50 \\
Vittaria elongata Sw. & 0.67 & 7.00 & 4.14 & 11.81 \\
\hline
\end{tabular}

The coverage percentage of epiphytic fern species growing on the trunk of $\mathrm{C}$. junghuhniana

The highest value of the coverage percentage of the epiphytic species growing on the tree fern $C$. junghuhniana occurred in Nephrolepis davalliodes. This species had the highest coverage percentage at any altitude intervals and the highest percentage value among species growing on the scaly tree fern. The total average of $N$. davalliodes covering percentage was $43.49 \%$. N. davalliodes is common species in forests at middle elevations (800-1600 $\mathrm{m}$ ) or higher (up to $2100 \mathrm{~m}$ ) in the Malesian region (Hovenkamp and Miyamoto 2005).

Asplenium nidus showed the second-highest of total coverage percentage. This species also tended to grow at the third interval. Bird's nest fern, A. nidus, is an important species in the rainforest canopy. They function in the effectiveness of contemporary climate buffer, and they are one of the most widely distributed epiphytes and have an important ecological role in Paleotropics (Ellwood and Foster 2004).

\section{Ecological Index Analysis of epiphytic ferns}

The results of the analysis of the ecological index of epiphytic ferns growing at three intervals trunk of $C$. junghuhniana were presented in Table 4. Shannon-Wiener diversity index $\left(\mathrm{H}^{\prime}\right)$ ranged between 1.124-1.496. Margalef Dominance Index (C) resulted in the value 0.022-0.042 and Pielou Evenness Index (E) of the observations resulted in the value $0.170-0.225$. Shannon-Wiener Diversity Index, Dominance Index, and Average Similarity Index $(S)$ of this study were lower than those reported by Schneider \& Schmitt (2011) in Brazil $(\mathrm{H}=1.766 ; \mathrm{E}=0.737)$, an epiphytic fern community growing on Alsophila setosa in semi-deciduous forest in South Brazil. 
Tabel 4. Ecological Index analysis of epiphytic ferns growing at three intervals trunk of $C$. junghuhniana in Gede-Pangrango National Park

\begin{tabular}{lcccc}
\hline Interval & S Average $\mathbf{\pm}$ SD & $\mathbf{H}^{\prime}$ & $\mathbf{C}$ & $\mathbf{E}$ \\
\hline $1 \mathrm{~m}$ & $4.543 \pm 4.201$ & 1.124 & 0.022 & 0.170 \\
$2 \mathrm{~m}$ & $8.314 \pm 5.284$ & 1.438 & 0.034 & 0.217 \\
$3 \mathrm{~m}$ & $8.571 \pm 4.282$ & 1.496 & 0.042 & 0.225 \\
\hline
\end{tabular}

Notes: SD: Deviation Standart; H': Shannon Weinner Index; C: Margelaf Dominant Index; E: Piolou Index (Evennes)

According to Magurran (1988), a low level of evenness will be stated when the $\mathrm{E}$ value is less than 0.3. Evenness otherwise being when the value $\mathrm{E}$ ranges between 0.3-0.6, and evenness is high level when the value is greater than 0.6. This value indicates evenness of epiphytic ferns growing on $C$. junghuhniana classified as moderate, Pielou evenness index (E) was 0.45-0.62, at the first and secondmeter intervals, while at intervals of three meters were high. Therefore, based on the analysis of the ecological index, it is concluded that the community of epiphytic ferns growing on trunk of $C$. junghuhniana is at moderate diversity, productivity is enough, the condition of the ecosystem is quite balanced with ecological pressures moderate.

In conclusion, Cyathea junghuhniana is an important microhabitat for epiphytes in the forest understorey. Trunk of the tree fern $C$. junghuhniana is highly suitable habitat for epiphytic ferns in the wet tropical forest. The total number of epiphytic ferns species found growing on the tree fern in Gede-Pangrango National Park was 12 species belonging to 9 genera and 6 families. The epiphytic ferns growing on the tree fern could be classified into 2 types, namely habitual and accidental holoepiphytes. From those two types, holo-epiphytic ferns were dominant.

The highest species richness of epiphytic ferns growing on $C$. junghuhniana belonged to the family Polypodiaceae. The species richness estimation curve for the total sample indicated that 35 samples of tree fern were enough to figure out the diversity of epiphytic ferns growing on the tree fern in this area. Species with the highest importance value index (IVI $=63.57 \%)$ and vertical amplitude were Nephrolepis davallioides, with increasing frequency from bottom to top of the caudex.

\section{ACKNOWLEDGEMENTS}

$\mathrm{TNgP}, \mathrm{UH}$ and $\mathrm{H}$ designed the study. $\mathrm{UH}$ assembled the data. $\mathrm{UH}$ and $\mathrm{TNgP}$ analyzed the data. $\mathrm{UH}, \mathrm{TNgP}$ and $\mathrm{H}$ prepared Indonesian manuscript. TNgP prepared English manuscript. The first author was supported by Bidikmisi (2012-2016) of DIKTI grant. We thank Dr. Ibnul Qayim and Taruni Sri Prawasti (Department of Biology, Bogor Agricultural University, Indonesia) for reading and making suggestions to improve the manuscript. The first author wishes to thank Rahmasari Inayah for helping in the statistical analyses, Syifa Rosyanah and Suci Safari Muhazirin for their help and companying in the field. We are grateful to Dr. Graham Eagleton (Australia) for providing valuable comments and reading the abstract of the first manuscript.

\section{REFERENCES}

Acebey AR, Krömer T, Kessler M. 2017. Species richness and vertical distribution of ferns and lycophytes along an elevational gradient in Los Tuxtlas, Veracruz, Mexico. Flora 235: 83-91. DOI: 10.1016/j.flora.2017.08.003.

Aguirre A, Guevara R, Garci'a, M, Lo' pez JC. 2010. Fate of epiphytes on phorophytes with different architectural characteristics along the perturbation gradient of Sabal mexicana forests in Veracruz, Mexico. J Veg Sci 21 (1): 6-15. DOI: 10.1111/j.1654-1103.2009.01131.x.

Bartels SF, Chen HYH. 2012. Mechanisms regulating epiphytic plant diversity. Crit Rev Plant Sci 31 (5): 391-400. DOI: 10.1080/07352689.2012.680349.

Batke S. 2012. Epiphytes: a study of the history of forest canopy research. Plymouth Stud Sci 5 (1): 253-268.

Bhatt A, Gairola S, Govender Y, Baijnath H, Ramdhani S. 2015. Epiphyte diversity on host trees in an urban environment, eThekwini Municipal Area, South Africa. N Z J Bot 53 (1): 24-37. DOI: 10.1080/0028825X.2014.1000935.

Bianchi JS, Kersten RA. 2014. Edge effect on vascular epiphytes in a subtropical Atlantic Forest. Acta Bot Bras 28 (1): 120-126. DOI: 10.1590/S0102-33062014000100012.

Bittner J, Trejos-Zelaya J. 1997. Analysis of the vascular epiphytes of tree ferns in a montane rain forest in Costa Rica. Rev Math: Teor' 1 a Appl 4 (2): 63-68. DOI: 10.15517/rmta.v4i2.148

Blair DP, Blanchard W, Banks SC, Lindenmayer DB. 2017. Non-linear growth in tree ferns, Dicksonia antarctica and Cyathea australis. PloS ONE 12 (5): e0176908. DOI: 10.1371/journal.pone.0176908.

Boelter CR, Dambros CS, Nascimento HEM, Zartman CE. 2014. A tangled web in tropical tree-tops: Effects of edaphic variation, neigh bourhood phorophyte composition and bark characteristics on epiphytes in a central Amazonian forest. J Veg Sci 25 (4): 1090-1099. DOI: $10.1111 /$ jvs. 12154 .

Brighigna L, Montaini P, Favilli F, Trejo AC. 1992. Role of the nitrogenfixing bacterial microflora in the epiphytism of Tillandsia (Bromeliaceae). Am J Bot 79 (7): 723-727. DOI: 10.1002/j.15372197.1992.tb13646.x.

Burns KC, Zotz G. 2010. A hierarchical framework for investigating epiphyte assemblages: Networks, meta-communities, and scale. Ecology 91 (2): 377-385. DOI: 10.1890/08-2004.1.

Castelloa ACD, Coelhob S, Cardoso-Leitec E. 2017. Lianas, tree ferns and understory species: Indicators of conservation status in the Brazilian Atlantic Rainforest remnants, southeastern Brazil. Braz J Biol 77 (2): 213-226. DOI: 10.1590/1519-6984.07715.

Chambers SM, Watkins JE Jr., Sessa EB. 2017. Differences in dehydration tolerance among populations of a gametophyte-only fern. Am J Bot 104 (4): 598-607. DOI: 10.3732/ajb.1600279.

CITES. 2019. Convention on International trade in endangered species of wild fauna and flora. Appendices I, II and III. https://cites.org/sites/default/files/eng/app/2019/E-Appendices-201911-26.pdf. [6-7-2021]

de la Rosa-Manzano E, Mendieta-Leiva G, Guerra-Pe'rez A, AguilarDorantes KM, Arellano-Me'ndez LU, Torres-Castill JA. 2019. Vascular epiphytic diversity in a neotropical transition zone is driven by environmental and structural heterogeneity. Trop Conserv Sci 12: 1-16. DOI: 10.1177/1940082919882203.

Deng C, Daley T, Smith AD. 2015. Applications of species accumulation curves in large-scale biological data analysis. Quant Biol 3 (3): 135144. DOI: $10.1007 / \mathrm{s} 40484-015-0049-7$.

Díaz IA, Sieving KE, Pena-Foxon M, Armesto JJ 2012. A field experiment links forest structure and biodiversity: Epiphytes enhance canopy invertebrates in Chilean forests. Ecosphere 3 (1): 1-17. DOI: 10.1890/ES11-00168.1

Ditjen PHKA. Direktorat Jenderal Perlindungan Hutan dan Konservasi Alam. 2008. Buku Informasi 50 Taman Nasional di Indonesia. Sub Direktorat Informasi Konservasi Alam, Bogor, Indonesia. [Indonesian]

Eleute'rio AA, Pe'rez-salicrup D. 2006. Management of tree ferns (Cyathea spp.) for handicraft production in Cuetzalan, Mexico. Econ 
Bot 60: $182-186$ DOI:

$10.1663 / 0013$ 0001(2006)60[182:MOTFCS]2.0.CO;2.

Ellwood MDF, Foster WA. 2004. Doubling the estimate of invertebrate biomass in a rainforest canopy. Nature 429 (6991): 549-551. DOI 10.1038 /nature02560.

Eskova AK, Prilepsky NG, Antipina VA, Abakumov EV, Thinh NgV. 2020. Formation of epiphytic communities in man-made forests of South Vietnam. Russ J Ecol 51 (3): 206-214. DOI: 10.1134/S1067413620030078.

Fraga LL, Silva LB, Schmitt JL. 2008. Composição e distribuição vertical de pteridófi tas epifíticas sobre Dicksonia sellowiana Hook (Dicksoniaceae), em fl oresta ombrófi la mista no sul do Brasil. Biota Neotrop 8 (4): 123-129. DOI: 10.1590/S1676-06032008000400011.

Gabriel y Galaân JM, Murciano A, Sirvent L, Saânchez A, Watkins JE. 2018. Germination fitness of two temperate epiphytic ferns shift under increasing temperatures and forest fragmentation. PLoS ONE 13 (5): e0197110. DOI: 10.1371/journal.pone.0197110.

Gonza'lez DCG, Quiel CR, Zotz G, Bader MY. 2017. Species richness and biomass of epiphytic vegetation in a tropical montane forest in Western Panama. Trop Conserv Sci 10: 1-17. DOI 10.1177/1940082917698468

Gotelli NJ, Colwell RK. 2001. Quantifying biodiversity: procedures and pitfalls in the measurement and comparison of species richness. Ecol Lett 4 (4): 379-391. DOI: 10.1046/j.1461-0248.2001.00230.x.

Gotsch SG, Nadkarni N, Amici A. 2016. The functional roles of epiphytes and arboreal soils in tropical montane cloud forests. J Trop Ecol 32 (5): 455-468. DOI: 10.1017/S026646741600033X.

Gunawan W, Sambas Basuni S, Indrawan A, Prasetyo LB, Soedjito H 2011. Analisis komposisi dan struktur vegetasi terhadap upaya restorasi kawasan hutan Taman Nasional Gunung Gede Pangrango. JPSL 1 (2): 93-105. [Indonesian]

Hayasaka D, Kimura N, Fujiwara K, Thawatchai W, Nakamura T. 2012. Relationship between microenvironment of mangrove forests and epiphytic fern species richness along the Pan Yi River, Thailand. J Trop For Sci 24 (2): 265-274

Hegarty EE. 1991. Vine-host interactions. In: Putz FE, Mooney HA (eds) The Biology of Vines. Cambridge University, Cambridge, UK.

Holttum RE. 1965. Tree-ferns of the genus Cyathea in Java. Reinwardtia 7(1):5-8.

Holttum RE. 1966. A Revised Flora of Malaya. II. Ferns of Malaya. Gov Print Office, Singapore.

Hovenkamp PH, Bosman MTM, Hennipman E, Nooteboom HP, RödlLinder G, Roos MC. 1998. Polypodiaceae. In: Kalkman C, Kirkup DW, Nooteboom HP, Saw LG, Stevens PF, de Wilde WJJO (eds) Flora Malesiana, Ser. II, Ferns and Fern Allies 3 Rijksherbarium/Hortus Botanicus, Leiden.

Hovenkamp PH, Miyamoto F. 2005. A conspectus of the native and naturalized species of Nephrolepis (Nephrolepidaceae) in the world. Blumea 50 (2): 279-322. DOI: 10.3767/000651905X623003.

Huang JB, Wen-Yao Liu W-Y, Li S, Song L, Lu H-Z, Shi X-M, Chen X, Hu T, Liu S, Liu T. 2019. Ecological stoichiometry of the epiphyte community in a subtropical forest canopy. Ecol Evol 9 (24): 143941440. DOI: $10.1002 /$ ece 3.5875.

Ismail MH, Fuad MFA, Zaki PH, Jemali NJM. 2017. Analysis of importance value index of unlogged and logged peat swamp forest in Nenasi Forest Reserve, Peninsular Malaysia. Bonorowo Wetlands 7 (2): 74-78. DOI: 10.13057/bonorowo/w070203.

Jiménez-López DA, Martínez-Camilo R, Martínez-Meléndez N, Kessler M. 2020. Diversity of epiphyte ferns along an elevational gradient in El Triunfo Biosphere Reserve, southern Mexico. Plant Ecol Evol 153 (1): 12-21. DOI: 10.5091/plecevo.2020.1573.

Klinghardt M, Zotz G. 2021 Abundance and seasonal growth of epiphytic ferns at three sites along a rainfall gradient in Western Europe. Flora 274: 151749. DOI: 10.1016/j.flora.2020.151749.

Kramer KU, Viane R. 1990. Aspleniaceae. In: Kramer KU, Green PS (eds) Pteridophytes and Gymnosperms (The Families and Genera of Vascular Plants Vol I). Springer-Verlag, Berlin. DOI: 10.1007/978-3662-02604-5 14

Lehnert M, Duque WDR, Fernando L, Gallego G, Tejedor A. 2019. New additions of scaly tree ferns (Cyatheaceae) to the flora of Colombia Am Fern J 109 (2): 77-120. DOI: 10.1640/0002-8444-109.2.77.

Lu H-Z, Song L, Liu W-Y, Xu X-L, Hu Y-H, Shi X-M, Li S, Ma W-Z, Chang Y-F, Fan Z-X, Lu S-G, Wu Y, Yu F-H. 2016. Survival and growth of epiphytic ferns depend on resource sharing. Front Plant Sci 7: 416. DOI: $10.3389 /$ fpls.2016.00416
Machado LS, Gonzatti F, Windisch PG. 2016. Epiphytic ferns in swamp forest remnants of the coastal plain of southern Brazil: latitudinal effects on the plant community. Acta Bot Bras 30 (4): 644-657. DOI: 10.1590/0102-33062016abb0319.

Magurran AE. 1988. Measuring Biological Diversity. TJ International, Padstow, Corbwall, United Kingdom.

Mandal KK, Kar T, Pattanaik C, Reddy CS. 2020. A census of pteridophytes in Eastern Ghats, India. Trop Plant Res 7 (1): 117-125. DOI: $10.22271 /$ tpr.2020.v7.i1.016

Mao Cx, Colwell RK, Chang J. 2005. Estimating the species accumulation curve using mixtures. Biometrics 61 (2): 433-441. DOI: 10.1111/j.1541-0420.2005.00316.x.

Medeiros AC, Loope LL, Anderson S J. 1993. Differential colonization by epiphytes on native (Cibotium spp.) and alien (Cyathea cooperi) tree ferns in a Hawaiian rain forest. Selbyana 14: 71-74.

Mehltreter K, Hooper EA. 2013. Annual Review of Pteridological Research 26: 1-102.

Michael P. 1984. Ecological Methods for Field and Laboratory Investigations. TataMc Graw Hill Publishing Co. Ltd., New Delhi, India.

Moran RC, Klimas S, Carlsen M. 2003. Low-trunk epiphytic ferns on tree ferns versus Angiosperms in Costa Rica. Biotropica 35 (1): 48-56. DOI: 10.1111/j.1744-7429.2003.tb00261.x.

Moulatlet GM, Zuquim G, Tuomisto H. 2019. The role of soils for pteridophyte distribution in tropical American forests. Fern Gaz 21 (1): 1-20.

Mountier CF, Case BS, Perrie LR, Brownsey P, Paterson AM, Curran TJ, Buckley HL. 2018. Patterns of range size in New Zealand ferns and lycophytes. N Z J Bot 42 (2): 248-261. DOI: 10.20417/nzjecol.42.22.

Mueller-Dombois D, Ellenberg H. 1974. Aims and Methods of Vegetation Ecology. New York, Wiley.

Mulyana A, Syarifudin D, Suheri H. 2015. Taman Nasional Gunung Gede Pangrango Selayang Pandang. Balai Besar Taman Nasional Gunung Gede Pangrango, Cianjur. [Indonesian]

Nagalingum NS, Knerr N, Laffan SW, González-Orozco CE, Thornhill AH, Miller JT, Mishler BD. 2015. Continental scale patterns and predictors of fern richness and phylogenetic diversity. Front Genet 6: 132. DOI: $10.3389 /$ fgene.2015.00132.

Nasution T, Junaedi DI. 2017. Keanekaragaman dan komposisi tumbuhan epifit berpembuluh padapaku tiang (Cyathea spp.) di Kebun Raya Cibodas, Jawa Barat. Pros Sem Nas Masy Biodiv Indon 3 (3): 453 460. DOI: 10.13057/psnmbi/m030326. [Indonesian]

Nettesheim FC, Damasceno ER, Sylvestre LS. 2014. Different slopes of a mountain can determine the structure of ferns and lycophytes communities in a tropical forest of Brazil. An Acad Bras Cienc 86 (1): 199-210. DOI: 10.1590/0001-3765201495912

Nieder J, Engwald S, Klawun M, Barthlott W. 2000. Spatial distribution of vascular epiphytes (including hemiepiphytes) in a lowland Amazonian rain forest (Surumoni Crane plot) of southern Venezuela. Biotropia 32 (3): 385-396. DOI: 10.1111/j.1744-7429.2000.tb00485.x

Nitta JH, Watkins JE Jr, Davis CC. 2020. Life in the canopy: Community trait assessments reveal substantial functional diversity among fern epiphytes. New Phytol 227 (6): 1885-1899. DOI: 10.1111/nph.16607.

Odum EP. 1998. Dasar-Dasar Ekologi. UGM Press, Yogyakarta, Indonesia.

Oldekop JA, Bebbington AJ, Truelove NK, Tysklind N, Villamarı'n S, Preziosi RF. 2012. Co-Occurrence patterns of common and rare leaflitter frogs, epiphytic ferns and dung beetles across a gradient of human disturbance. PLoS ONE 7 (6): e38922. DOI: 10.1371/journal.pone.0038922.

Piggott AG, Piggott JC. 1988. Ferns of Malaysia in Colour. Tropical Press, Kuala Lumpur.

Pouteau R, Maeyer JY, Blanchard P, NITTA JH, Terorotua M, Taputuaral R. 2016. Fern species richness and abundance are indicators of climate change on high-elevation islands: Evidence from an elevational gradient on Tahiti (French Polynesia). Clim Change 138 (1): 143-156. DOI: 10.1007/s10584-016-1734-x

PPG I (The Pteridophyte Phylogeny Group I). 2016. A communityderived classification for extant lycophytes and ferns. J Syst Evol 54 (6): 563-603. DOI: $10.1111 /$ jse.12229.

Praptosuwiryo TNg, Sumanto, Cahyaningsih R. 2019. Diversity and host preferences of ferns and lycopods epiphytes on palm trees. Biodiversitas 20 (12): 3731-3740. DOI: 10.13057/biodiv/d201236.

Price MG. 1977. Philippine Dryopteris. Gard Bull Singap 30: 239-250.

Quaresma AC, Jardim MAG. 2014. Floristic composition and spatial distribution of vascular epiphytes in the restingas of Maracanã, Brazil. 
Acta Bot Bras 28 (1): 68-75. DOI: $10.1590 / \mathrm{S} 0102$ 33062014000100007.

Quaresma AC, Piedade MTF, Feitos YO, Wittmann F, ter Steege H. 2017. Composition, diversity and structure of vascular epiphytes in two contrasting Central Amazonian floodplain ecosystems. Acta Bot Bras 31 (4): 686-697. DOI: 10.1590/0102-33062017abb0156.

Ramírez-Barahona S, Luna-Vega I, Tejero-Díez D. 2011. Species richness, endemism, and conservation of American tree ferns (Cyatheales). Biodivers Conserv 20 (1): 59-72. DOI: 10.1007/s10531010-9946-2.

Riefner RE Jr, Smith AR. 2019. New and noteworthy epiphytic ferns from the urban forests of coastal southern California, U.S.A. Phytologia 101 (1): 81-112.

Roberts NR, Dalton PJ, Jordan GJ. 2005. Epiphytic ferns and bryophytes of Tasmanian tree-ferns: A comparison of diversity and composition between two host species. Aust Ecol 30 (2): 146-154. DOI 10.1111/j.1442-9993.2005.01440.x.

Rödl-Linder G. 1990. A monograph of the fern genus Goniophlebium. Blumea 34 (2): 277-423.

Sanger JC, Kirkpatrick JB. 2015. Moss and vascular epiphyte distributions over host tree and elevation gradients in Australian subtropical rainforest. Aust J Bot 63 (8): 696-704. DOI: 10.1071/BT15169.

Scheffers BR, Phillips BL, Shoof LP. 2014. Asplenium bird's nest ferns in rainforest canopies are climate-contingent refuges for frogs. Global Ecol Conserv 2: 37-46. DOI: 10.1016/j.gecco.2014.06.004.

Schmitt JL, Budke JC, Windisch PG. 2005. Aspectos florísticos e ecológicos de pteridófitas epifíticas em cáudices de Dicksonia sellowiana Hook. (Pteridophyta, Dicksoniaceae), São Francisco de Paula, RS, Brasil. Pesquisas, Série Botânica 56 (1): 161-172

Schmitt JL, Fleck R, Burmeister EL, Rubio MAK. 2006. Diversity and biological forms of Pteridophytes of National Forest of Cinnamon, Rio Grande do Sul: Contributions to the Management Plan. Pesquisas, Botânica 57: 275-288.

Schmitt JL, Windisch PG. 2010. Biodiversity and spatial distribution of epiphytic ferns on Alsophila setosa Kaulf. (Cyatheaceae) caudices in Rio Grande do Sul, Brazil. Braz J Biol 70 (3): 521-528. DOI: 10.1590/S1519-69842010000300008

Schneider PH, Schmitt JL. 2011. Composition, community structure and vertical distribution of epiphytic ferns on Alsophila setosa Kaulf., in semideciduous seasonal forest, Morro Reuter, RS, Brazil. Acta Bot Bras 25 (3): 557-565. DOI: 10.1590/S0102-33062011000300007.

Schneider PH, Schmitt JL. 2011. Composition, community structure and vertical distribution of epiphytic ferns on Alsophila setosa Kaulf., in semideciduous seasonal forest, Morro Reuter, RS, Brazil. Acta Bot Bras 25 (3): 557-565. DOI: 10.1590/S0102-33062011000300007.

Schwartz CE, de Gasper AL 2020. Environmental factors affect population structure of tree ferns in the Brazilian subtropical Atlantic Forest. Acta Bot Bras 34 (1): 204-213. DOI: 10.1590/0102$33062019 \mathrm{abb} 0338$.

Shen T-J, Chao A, Lin C-F. 2003. Predicting the number of new species in further taxonomic sampling. Ecology 84 (3): 798-804. DOI: 10.1890/0012-9658(2003)084[0798:PTNONS]2.0.CO;2.
Sota ER. 1971. El epifitismo y las pteridofitas en Costa Rica (America Central). Nova Hedwigia 21 (2-4): 401-465.

Sota ER. 1972. Las pteridofitas y el epifitismo en el Departamento del Choco (Colombia). Anales de la Sociedad Cientifica Argentina 31 (56): 245-278.

Stanton DE, Chavez JH, Villegas L, Villasante F, Armesto J, Hedin LO, Horn H. 2014. Epiphytes improve host plant water use by microenvironment modification. Funct Ecol 28 (5): 1274-1283. DOI: $10.1111 / 1365-2435.12249$.

Steege Ter H, Cornelissen JHC. 1989. Distribution and ecology of vascular epiphytes in lowland rain forest of Guyana. Biotropica 21 (4): $331-339$. DOI: $10.2307 / 2388283$.

Steenis CGGJ van.1972. The Mountain Flora of Java. E.J.Brill, Leiden.

Sugita N, Ootsuki R, Fujita T, Murakami N, Ueda K. 2013. Possible spore dispersal of a Bird-nest fern Asplenium setoi by Bonin flying foxes Pteropus pselaphon. Mammal Stud 38 (3): 225-229. DOI: 10.3106/041.038.0301

Sureshkumar J, Ayyanar M, Silambarasan R. 2020. Pteridophyte species richness along elevation gradients in Kolli Hills of the Eastern Ghats, India. J Asia-Pac Biodivers 13 (1): 92-106. DOI: 10.1016/j.japb.2019.11.008.

Tessler N, Wittenberg L, Greenbaum N. 2016. Vegetation cover and species richness after recurrent forest fires in the Eastern Mediterranean ecosystem of Mount Carmel, Israel. Sci Tot Environ 572: 1395-1402. DOI: 10.1016/j.scitotenv.2016.02.113.

Testo WL, Watkins JEJ. 2013. Understanding mechanisms of rarity in pteridophytes: Competition and climate change threaten the rare fern Asplenium scolopendrium var americanum (Aspleniaceae). Am J Bot 100 (11): 2261-2270. DOI: pdf/2210.3732/ajb.1300150.

Wagner K, Mendieta-Leiva G, Zotz G. 2015. Host specificity in vascular epiphytes: A review of methodology, empirical evidence and potential mechanisms. AoB Plants 7. DOI: 10.1093/aobpla/plu092.

Wang X, Long W, Schamp BS, Yang X, Kang Y, Xie Z, Xiong M. 2016. Vascular epiphyte diversity differs with host crown zone and diameter, but not orientation in a tropical cloud forest. PLoSONE 11 (7): e0158548. DOI: 10.1371/journal.pone.0158548.

Watkins Jr JE, Cardelu's CL. 2012. Ferns in an Angiosperm world: Cretaceous radiation into the epiphytic niche and diversification on the forest floor. Intl J Plant Sci 173 (6): 695-710. DOI: $10.1086 / 665974$.

Zotz G, Schultz S. 2008. The vascular epiphytes of a lowland forest in Panama-species composition and spatial structure. Plant Ecol 195 (1): 131-141. DOI: 10.1007/s11258-007-9310-0.

Zotz G. 2007. Johansson revisited: The spatial structure of epiphyte assemblages. J Veg Sci 18 (1): 123-130. DOI: 10.1111/j.16541103.2007.tb02522.x.

Zotz G. 2013. The systematic distribution of vascular epiphytes-a critical update. Bot J Linn Soc 171 (3): 453-481. DOI: 10.1111/boj.12010.

Zotz G. 2016. Plants on Plants-The Biology of Vascular Epiphytes. Springer International Publishing, Switzerland. DOI: 10.1007/978-3319-39237-0 